University of Nebraska - Lincoln

DigitalCommons@University of Nebraska - Lincoln

West Central Research and Extension Center, North Platte

Agricultural Research Division of IANR

2009

Functionally Similar Species Confer Greater Resistance to

Invasion: Implications for Grassland Restoration

\author{
Stephen L. Young \\ University of Nebraska - Lincoln, steve.young@usu.edu \\ Jacob N. Barney \\ University of California, Davis \\ Guy B. Kyser \\ University of California, Davis \\ Tracy S. Jones \\ Pflugerville, $T X$ \\ Joseph M. DiTomaso \\ University of California, Davis, jmditomaso@ucdavis.edu
}

Follow this and additional works at: https://digitalcommons.unl.edu/westcentresext

Part of the Agriculture Commons

Young, Stephen L.; Barney, Jacob N.; Kyser, Guy B.; Jones, Tracy S.; and DiTomaso, Joseph M., "Functionally Similar Species Confer Greater Resistance to Invasion: Implications for Grassland Restoration" (2009). West Central Research and Extension Center, North Platte. 6.

https://digitalcommons.unl.edu/westcentresext/6

This Article is brought to you for free and open access by the Agricultural Research Division of IANR at DigitalCommons@University of Nebraska - Lincoln. It has been accepted for inclusion in West Central Research and Extension Center, North Platte by an authorized administrator of DigitalCommons@University of Nebraska - Lincoln. 
Published in Restoration Ecology 17:6 (2009), pp.884-892; doi 10.1111/j.1526-100X.2008.00448.x Copyright (C) 2009 Society for Ecological Restoration International; published by Wiley-Blackwell. Used by permission.

Published online October 6, 2008

\title{
Functionally Similar Species Confer Greater Resistance to Invasion: Implications for Grassland Restoration
}

\author{
Stephen L. Young, ${ }^{1}$ Jacob N. Barney, ${ }^{2}$ Guy B. Kyser, ${ }^{2}$ Tracy S. Jones, ${ }^{3}$ and Joseph M. DiTomaso ${ }^{2}$ \\ ${ }^{1}$ Department of Land, Air, and Water Resources, University of California, Davis, CA 95616, U.S.A. \\ 2 Department of Plant Sciences, University of California, Davis, CA 95616, U.S.A. \\ ${ }^{3} 1009$ Walter Court, Pflugerville, TX 78660, U.S.A. \\ Corresponding author - J. M. DiTomaso, email jmditomaso@ucdavis.edu
}

\begin{abstract}
Plant community functional composition can be manipulated in restored ecosystems to reduce the establishment potential of invading species. This study was designed to compare invasion resistance among communities with species functionally similar or dissimilar to yellow starthistle (Centaurea solstitialis), a late-season annual. A field experiment was conducted in the Central Valley of California with six experimental plant communities that included (1) six early-season native annual forbs (AF); (2) five late-season native perennials and one summer annual forb (NP); (3) a combination of three early-season native annual forbs and three late-season native perennials (FP); (4) six early-season non-native annual grasses (AG); (5) monoculture of the late-season native perennial grass Elymus glaucus (EG); and (6) monoculture of the late-season native perennial Grindelia camporum (GC). Following establishment, C. solstitialis seed was added to half of the plots, and a monoculture of C. solstitialis (CS) was established as a control. Over a 5-year period, the $\mathrm{AF}$ and $\mathrm{AG}$ communities were ineffective at preventing $C$. solstitialis invasion. Centaurea solstitialis cover remained less than $10 \%$ in the FP and NP communities, except in year 1. By the fourth year, E. glaucus cover was greater than 50\% in NP and FP communities and had spread to all other communities (e.g., 27\% cover in CS in year 5). Communities containing E. glaucus, which is functionally similar to C. solstitialis, better resisted invasion than communities lacking a functional analog. In contrast, G. camporum, which is also functionally similar to C. solstitialis, failed to survive. Consequently, species selection for restored communities must consider not only functional similarity to the invader but also establishment success, competitiveness, and survivorship.
\end{abstract}

Keywords: Centaurea solstitialis, Elymus glaucus, functional similarity, Grindelia camporum

\section{Introduction}

Species diversity influences many plant community properties, such as primary production, nutrient cycling, hydrodynamics, and plant community resilience and resistance (Diaz et al. 2007). Highly diverse plant communities have been hypothesized to be more stable and thus more resistant to invasion of non-native species (Elton 1958). However, empirical studies have both supported (Tilman et al. 1996) and opposed (Robinson et al. 1995) the diversity-stability hypothesis. Tilman (1997) and Symstad (2000) suggest that functional diversity is a more accurate indicator of community stability or resistance to invasion than general species diversity. Additionally, Vitousek and Hooper (1997) and Brown et al. (1998) demonstrated that communities containing species functionally similar to the invader are more capable of resisting invasion compared to communities characterized simply by high species diversity. Functional groups are classified based on their ecological, morphological, physiological, biochemical, or life history characteristics (Lavorel et al. 2007). Thus, restored communities may better resist future invasions by incorporating species functionally similar to known high-risk invaders.

Most of the grasslands of the Central Valley of California have been invaded by non-native annual grasses. These annual grasses displaced communities of native perennial bunchgrasses and forbs beginning with the arrival of Europeans into California in the 1700s (Burcham 1956; Heady 1988). Fire suppression, agricultural disturbance, and overgrazing by cattle during periods of drought led to their dominance (Heady 1988). Once established, non-native annual grasses produce dense canopies that suppress the establishment of slower growing perennial bunchgrass seedlings (Rice et al. 1997).

More recently, many California grasslands, particularly in the Central Valley, are shifting from annual grasses to late-season deep-rooted annual forb species, particularly yellow starthistle (Centaurea solstitialis). This shift corre- 
lates with disturbance and canopy gaps, both of which increase light availability later in the growing season (Gerlach \& Rice 2003). In addition, these late-season forbs utilize deep soil moisture not available to shallow-rooted annual grasses (Gerlach 2004; Young 2007).

The initial displacement of native bunchgrass communities by non-native annual grasses was not a priority to most land managers because these communities continued to produce high-value forage. However, with the spread of C. solstitialis into grasslands, restoration of native grassland communities has become a greater concern for public land managers and private landowners (Bugg et al. 1997).

Centaurea solstitialis is believed to have arrived in California after 1849 as a contaminant in Chilean-grown alfalfa seed (Gerlach 1997b). Following its introduction into alfalfa fields in northern California, C. solstitialis spread to other locations, including grain fields, via tractors, and other equipment. By 1958, C. solstitialis was estimated to have invaded over 250,000 ha of California, mostly in range or grasslands (DiTomaso 2000). Over the past four decades, rapid and long-range dispersal of $C$. solstitialis has occurred through extensive road building, increased suburban development, and an expansion in the ranching industry (Gerlach 1997a). The current $C$. solstitialis infestation in California has been estimated at nearly 5.7 million ha (Pitcairn et al. 2006).

Unlike native perennial bunchgrasses, $C$. solstitialis has ruderal characteristics including high seed production (Roché et al. 1994), reduced seed dormancy, and rapid root development (Sheley et al. 1993; Benefield et al. 2001). Although C. solstitialis is an annual forb, its morphology and phenology are different from most annual grass and broadleaf species found in California grasslands. By comparison, it appears to be functionally similar to late-season perennial grasses and forbs in its resource allocation patterns and phenology (Gerlach \& Rice 2003; Gerlach 2004).

In this study, we compared resistance to C. solstitialis invasion in communities with species functionally similar (late season) or dissimilar (early season) to the invader or in combination (early and late season). To this end, we established communities of early-season non-native winter annual grasses, early-season native winter annual forbs, mixed late-season native perennial grasses, mixed earlyand late-season native forbs and perennial grasses, and monocultures of a late-season native perennial grass and native perennial forb with and without additions of $C$. solstitialis. We hypothesized that communities with species functionally equivalent to $C$. solstitialis would better resist invasion.

\section{Methods}

\section{Field Site}

The experiment was conducted at the University of California, Davis, in the western Sacramento Valley (northern Central Valley), on a level, open field. The soil was a coarseloamy mixed superactive nonacidic thermic Typic Xeroflu- vents (Xero Fluvic Entisol). The site was previously dominated by agricultural weeds (e.g., Bromus spp., Lolium spp., Convolvulus arvensis, Salsola tragus, Brassica spp., Sinapis arvensis, and Raphanus spp.). There was no record of Centaurea solstitialis at or near the research site prior to the initiation of the experiment.

\section{Experimental Design}

All species chosen were known to occur in grassland ecosystems near the study site. The native species selected were believed to be locally prevalent prior to the invasion of non-native winter annual grasses (Burcham 1956; McNaughton 1968; Heady 1988) or C. solstitialis (DiTomaso 2000). For this reason, these natives are considered the most suitable for restoration programs in northern California and surrounding regions (Bugg et al. 1997). Furthermore, all native species used in this study were commercially available through a local seed producer (Hedgerow Farms, Winters, CA, U.S.A.; hedgerowfarms.com) and are known to establish well under local conditions. Therefore, native species that are functionally similar to C. solstitialis, like tarweeds (Hemizonia spp)., were not included, as they are not commercially available and are unlikely to be used in a grassland restoration. The non-native annual grasses used in this study are common components of the Central Valley grasslands in California. Seeds of these species were collected the previous season or purchased from a local company (Valley Seeds, Fresno, CA, U.S.A.).

The experimental communities comprised annual or perennial forbs and grasses, with their functional group classification based on the timing of resource use according to Hickman (1993) and DiTomaso and Healy (2007) (Table 1). Non-native winter annual grasses grow primarily during the cool, wet season (first fall rain to early April), set seed by early summer, and are shallow rooted. In general, native annual forbs are phenologically similar to the non-native annual grasses. In contrast, the native perennials reach reproductive peak during the dry summer months with their roots typically exceeding $1 \mathrm{~m}$ in depth (DiTomaso et al. 2003).

Elymus glaucus and the other perennial grasses are morphologically different (fibrous roots, narrow leaves) than C. solstitialis but functionally similar (timing of soil water use). The perennial grasses have a dense, bunched growth habit, survive moderate drought conditions, and continue to grow during the summer, given adequate soil moisture. Among them, E. glaucus is considered to be one of the better adapted and more robust perennial grasses native to the Sacramento Valley (Knapp and Rice 1996; Bugg et al. 1997). Grindelia camporum, the only perennial forb used in the study, is most closely related taxonomically, morphologically, and functionally to C. solstitialis of those species in this study. Both G. camporum and C. solstitialis are characterized by late-season growth and flowering, deep roots, and water use timing. Therefore, monocultures of E. glaucus and G. camporum were established in addition to mixed communities. 
Table 1. Species compositions in six plant communities $(\mathrm{AG}=$ annual grass; $\mathrm{AF}=$ annual forb; $\mathrm{NP}=$ native perennial; $\mathrm{FP}=$ annual forbs and perennials; EG=Elymus glaucus; and GC =Grindelia camporum).

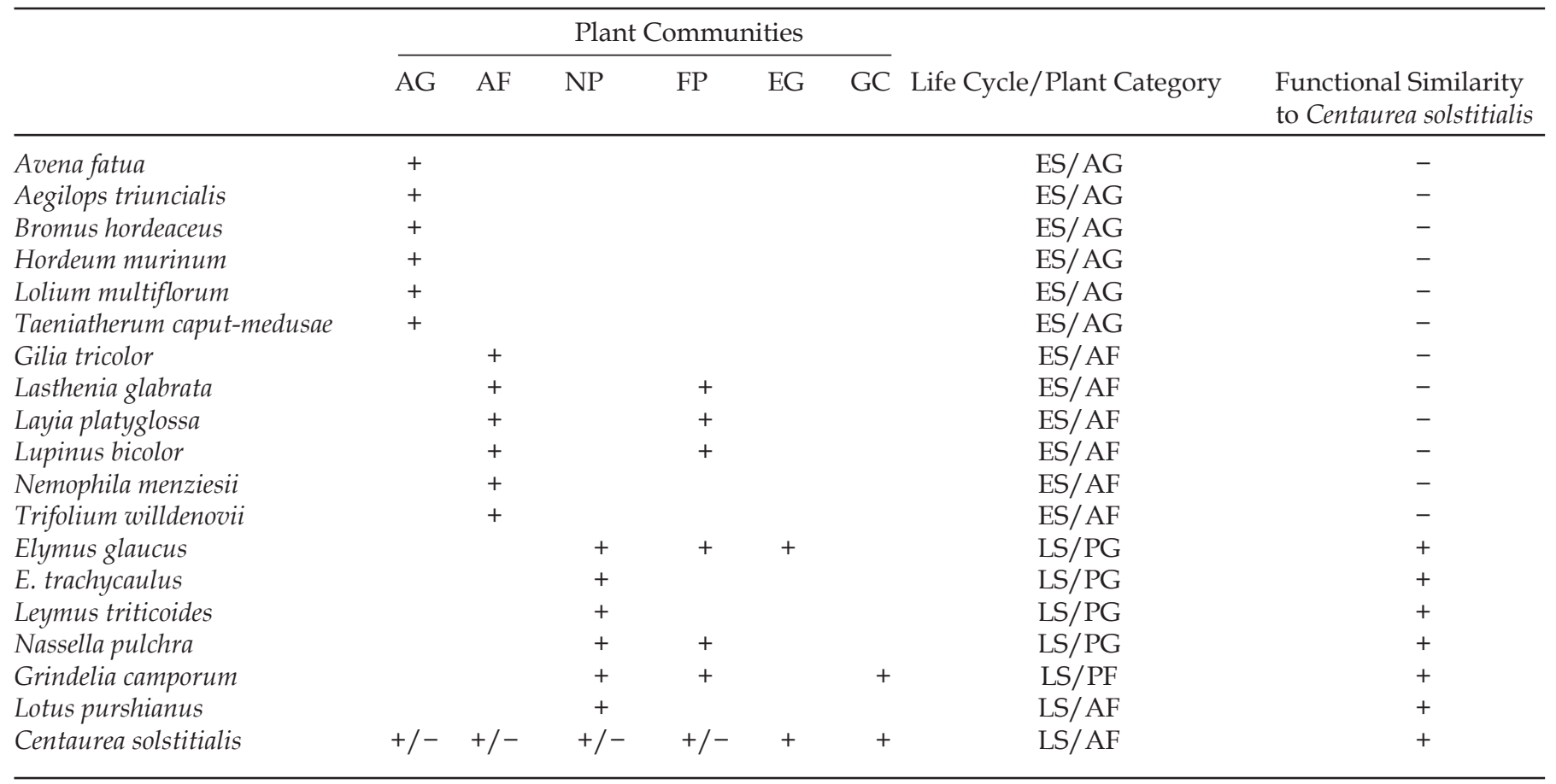

Each species is classified into the life cycles of early season (ES) or late season (LS), and plant category including annual grasses $(\mathrm{AG})$, annual forbs (AF), perennial grasses (PG), or perennial forbs (PF).

Communities were planted in a randomized complete block design with five replications in $4 \times 4-m$ plots with 2 -m-wide alleys between plots. Four mixed plant communities were established (Table 1): six native annual forbs $(\mathrm{AF})$, five native late-season perennials plus a late-season annual (NP), three native annual and three perennial species (FP), and six non-native annual grasses (AG). The plots of each of these community types were established, with half of them seeded with C. solstitialis (CS) in the following fall. Monocultures of E. glaucus (EG) and G. camporum (GC) were established in five plots each, and all the plots were seeded with C. solstitialis the following fall.

Seeds of each community were pre-mixed, broadcast by hand, and lightly raked to incorporate them into the soil. The total seeding rate was $22.4 \mathrm{~kg}$ pure live seed/ha, which is within the typical range of reseeding restoration programs (J. A. Anderson, Hedgerow Farms, personal communication). Live seed weights were based on germination and purity percentages. No supplemental irrigation or nutrients were applied. All plots were planted in fall 2000 following the first rains. To ensure seed viability, seeds of each species were planted in 1- $\mathrm{m}^{2}$ monoculture plots adjacent to the study site. All species in these plots germinated and established in the first season. Annual grass plots (AG) were planted in winter (January) 2002.

Seeds of C. solstitialis were collected locally in 2000. In fall 2001, 1 year after establishment of the native plant communities, $C$. solstitialis was broadcast seeded into the monoculture plots and half (five replicates) the $\mathrm{AF}, \mathrm{NP}$, and $\mathrm{FP}$ plots (hereafter, $\mathrm{AF}+\mathrm{CS}, \mathrm{NP}+\mathrm{CS}$, and FP + CS, respectively), whereas the other half were not seeded. A C. solstitialis (CS) monoculture treatment (five replicates) also was established for comparison. Similar to AF, NP, and FP plots, half of all the non-native annual grass (AG) plots established in winter 2002 were also overseeded with C. solstitialis (AG + CS) in fall 2002. Centaurea solstitialis was overseeded at a rate of 1,000 seeds $/ \mathrm{m}^{2}(2 \mathrm{~kg} / \mathrm{ha})$, which represents about $10 \%$ of the normal seed bank in a heavily infested area. This rate was intended to simulate a $90 \%$ seed bank reduction typically achieved following a 1- to 2year control program (DiTomaso et al. 1999). Restoration of a C. solstitialis-infested area usually requires 1 or 2 years of weed control to successfully establish native plant communities (DiTomaso et al. 2000).

Individual species cover measurements were taken in both spring and summer beginning in 2002 for all plots except AG. Monitoring of species in the AG plots began in summer 2003 and continued until summer 2005. Cover of all species was measured in all years and seasons except summer 2003. During this timing, cover was only recorded for C. solstitialis and G. camporum, owing to transition in project leadership. Measurements were conducted within permanent $0.5 \times 0.5-\mathrm{m}$ subplots in each corner of the plot (four subplots per plot), approximately $0.25 \mathrm{~m}$ from the plot edges. Relative species and thatch cover (and bare ground) were visually estimated to within $1 \%(0-10 \%)$ and thereafter to the nearest $5 \%$ (10-100\% cover) for a total of $100 \%$ cover. Subplot cover values were averaged for each plot. 
After 3 years of establishment without disturbance, the study site was mowed in November 2004 and 2005 to simulate fall grazing. Late-season grazing is a common practice in northern California rangelands and grassland restoration (Heady 1988).

\section{Statistical Analysis}

Total cover was analyzed by analysis of variance with the general linear model (GLM) procedure to assess the overall effect of Centaurea solstitialis on the experimental plant communities. Data was only collected at peak spring and summer biomass production, relating to early- and late-season functional groups. Therefore, within- and among-year covariations were minimized, precluding repeated measures analysis (Daniel 1999). Additionally, year-to-year variation prohibited statistical comparisons across years. Pairwise contrasts of $C$. solstitialis, E. glaucus, and G. camporum between commu- nity types were conducted based on the linear combination of cover data obtained from the overall analysis (Scheiner 2001). We performed statistical analyses only on cover of $C$. solstitialis and G. camporum in summer 2003 because cover data for other species (e.g., E. glaucus) were not available. All statistical analyses were performed with SAS (2002).

\section{Results}

Annual forb cover in AF and AF + CS (prior to seeding with CS) plots was 96\% in the spring after planting (2001) but declined to $13 \%$ by the fourth season after planting (data not shown). By 2005, spring flushes (<1\%) of Nemophila menziesii and Lasthenia glabrata were all that remained. After 2003, native annual forbs were rarely present $(<1 \%)$ in $\mathrm{AF}$ and FP communities, and most annual species were non-native forbs and grasses (Fig. 1C-F).
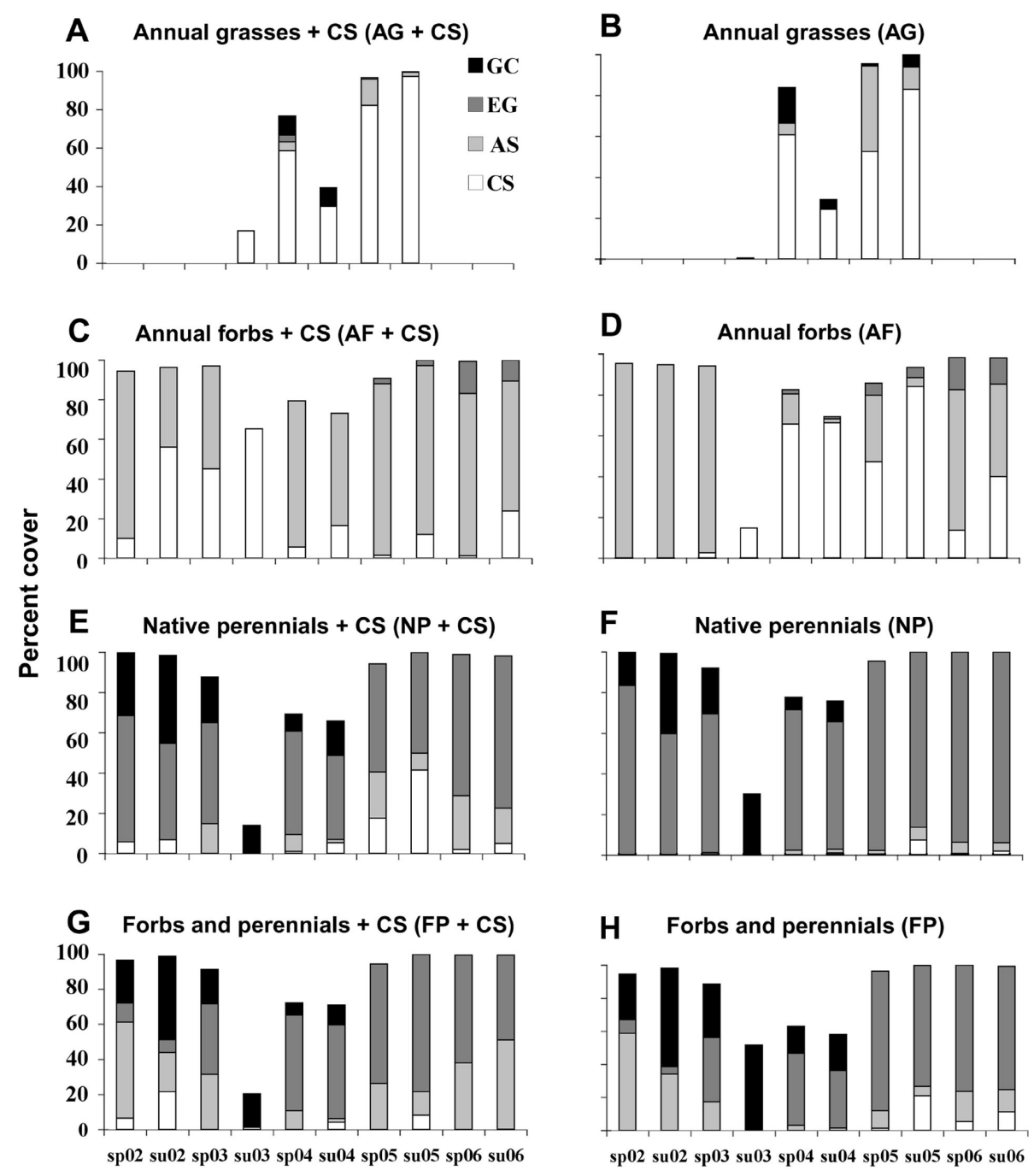

Figure 1. Percent cover from spring 2002 (sp02) through summer 2006 (su06) in (A) annual grasses with CS and (B) without CS, (C) native annual forbs with CS and (D) without CS, (E) native perennials with CS and (F) without CS, (G) and a mixture of native annual forbs and perennials with CS and (H) without CS showing Grindelia camporum (GC), Elymus glaucus (EG), annual species (AS), and Centaurea solstitialis (CS). AG and AG + CS plots were evaluated from sp04 to su05. Summer 2003 cover values only include C. solstitialis and G. camporum. Thatch and bare ground contributed to remainder of cover values not shown. 

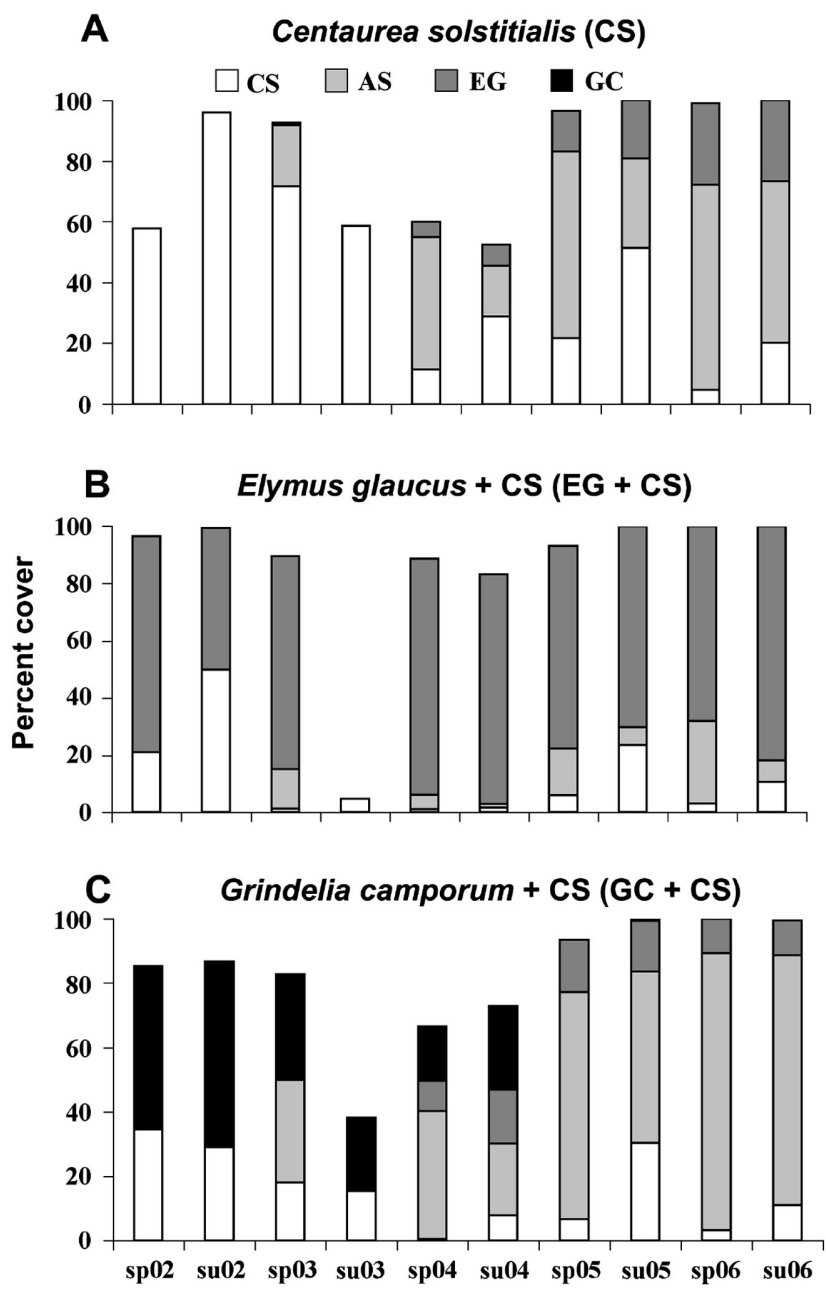

Figure 2. Percent cover from spring 2002 (sp02) through summer 2006 (su06) in a monocultures of (A) Centaurea solstitialis (CS), (B) Elymus glaucus with CS (EG + CS), and (C) Grindelia camporum with CS (GC + CS) showing G. camporum (GC), E. glaucus (EG), annual species (AS), and C. solstitialis (CS). Summer 2003 cover values only include C. solstitialis and G. camporum.

By spring 2003, the native summer perennials, E. glaucus and G. camporum, dominated $(>50 \%)$ all communities in which they were included (Figs. 1E-H \& 2B-C). The perennials E. trachycaulus, Nassella pulchra, and Leymus triticoides were only rarely present $(<1 \%)$ in NP and FP communities.

AG communities were dominated by Lolium multiflorum, which was seeded, and Bromus diandrus, which was present in the resident seed bank. The other seeded nonnative annual grasses (Table 1), which readily establish in many similar areas of California, did not establish in these plots presumably due to competition with L. multiflorum and B. diandrus.

\section{Invasion of Early-Season Communities}

Centaurea solstitialis established but was not dominant (16\% cover) in AG + CS plots in summer 2003, the first sea- son after seeding (Fig. 1A). This level of infestation was less than CS in monoculture in its first year of establishment (Fig. 2A) and statistically less than CS alone during the same summer 2003 time period (Table 2). By the second spring and summer (2004) after seeding, C. solstitialis was the most dominant species present in the AG + CS plots and even the AG plots that were not seeded with C. solstitialis (Fig. 1B). By 2004, the level of C. solstitialis infestation in the AG plots was not significantly different than the AG + CS plots (Table 3). Because there was no residual C. solstitialis seed bank present prior to the establishment of the study, the unseeded plots presumably were infested with C. solstitialis from adjacent seeded communities. In both the $\mathrm{AG}$ and the AG + CS plots, C. solstitialis cover peaked at greater than 80 by summer 2005 .

Annual forb communities (Fig. 1C-D) were also rapidly invaded by $C$. solstitialis. In overseeded plots (AF + CS), C. solstitialis cover peaked at $65 \%$ the second year following seeding (summer 2003; Fig. 1C), whereas in unseeded plots (AF), C. solstitialis did not become dominant until 2004 and peaked at 84\% cover in summer 2005 (Fig. 1D). Centaurea solstitialis cover was greater in seeded plots through summer 2003 but was significantly greater in unseeded plots in 2004 and 2005 (Table 3). After reaching peak cover, C. solstitialis declined in both AF + CS and AF plots. In summer 2003 and 2004, C. solstitialis cover was not significantly different in AF + CS plots versus CS monocultures (Table 2). In CS monoculture plots (Fig. 2A), C. solstitialis cover peaked at $96 \%$ the year after seeding (2002), declined to $29 \%$ by summer 2004 , peaked again at $50 \%$ in summer 2005 , and declined the following year to less than $20 \%$. Centaurea solstitialis populations commonly fluctuate with peak infestation years followed by reduced cover in subsequent years (Kyser \& DiTomaso, personal observation).

Interestingly, in years where C. solstitialis cover was significantly different between CS and AG + CS plots after the first year of establishment (2003), C. solstitialis cover was always higher in the AG + CS plots (Table 2). The opposite was true for CS versus AF + CS plots.

\section{Invasion of Late-Season Communities}

Unlike the annual plant communities, C. solstitialis was unable to dominate in either the seeded or unseeded native perennial communities (Fig. 1E-H). Centaurea solstitialis cover in plots with native perennials was always lower than in CS-only plots and was significantly different in most years (Table 2). By comparison, C. solstitialis cover was rarely different between seeded and unseeded NP or FP plots (Table 3).

In plant communities with perennial grasses, E. glaucus was the dominant species (Fig. 1E-H). However, E. glaucus establishment was delayed by annual species in the mixed FP communities, as compared to NP communities. Elymus glaucus cover was greater when planted alone or seeded with C. solstitialis (EG + CS) from 2002 to 2004 compared to the mixed communities with native perennials (Table 4). Centaurea solstitialis was competitive with E. glaucus in monoculture in the first summer after seeding and then de- 
clined in subsequent years (Fig. 2B). Overall, E. glaucus became the dominant species in all treatments where it was in the seeding mix.

Once established in the seeded plots, E. glaucus spread to most other communities (Figs. 1C-D \& 2A, C). Individual E. glaucus plants were first identified (1\% cover) in spring 2003 in the CS-only plots (data not shown). By 2006, E. glaucus cover reached $27 \%$ in CS plots. Satellite E. glaucus plants ap- peared in all other plots by summer 2005 (Figs. 1 \& 2).

By summer 2002, G. camporum cover ranged from 40 to $60 \%$ in mixed native perennial communities and GC + CS (Figs. 1E-H \& 2C) and was not significantly different in communities with and without CS (Table 5). In subsequent years, however, G. camporum cover declined, and by 2005, it was no longer present in any of the plots where it had previously established, including GC + CS (Fig. 2).

Table 2. Linear contrasts of Centaurea solstitialis cover between CS monocultures and mixed plant communities $(\mathrm{AG}=\mathrm{annual}$ grasses; $\mathrm{AF}=$ annual forbs; $\mathrm{NP}=$ native perennials; $\mathrm{FP}=$ annual forbs and perennials; $\mathrm{EG}=$ Elymus glaucus; $\mathrm{GC}=$ Grindelia camporum; $\mathrm{CS}=\mathrm{C}$. solstitialis $)$.

\begin{tabular}{|c|c|c|c|c|c|c|c|c|c|c|}
\hline \multirow[b]{2}{*}{$\begin{array}{l}\text { Treatment } \\
\text { Contrast }\end{array}$} & \multicolumn{2}{|c|}{2002} & \multicolumn{2}{|c|}{2003} & \multicolumn{2}{|c|}{2004} & \multicolumn{2}{|c|}{2005} & \multicolumn{2}{|c|}{2006} \\
\hline & $\begin{array}{c}\text { Spring } \\
(p<0.0001, \\
n=40)\end{array}$ & $\begin{array}{c}\text { Summer } \\
(p<0.0001, \\
n=50)\end{array}$ & $\begin{array}{c}\text { Spring } \\
(p<0.0001, \\
n=50)\end{array}$ & $\begin{array}{c}\text { Summer } \\
(p<0.0001, \\
n=60)\end{array}$ & $\begin{array}{c}\text { Spring } \\
(p<0.0001, \\
n=60)\end{array}$ & $\begin{array}{c}\text { Summer } \\
(p<0.0001, \\
n=60)\end{array}$ & $\begin{array}{c}\text { Spring } \\
(p<0.0001,( \\
n=60)\end{array}$ & $\begin{array}{c}\text { Summer } \\
(p<0.0001, \\
n=60)\end{array}$ & $\begin{array}{c}\text { Spring } \\
\left(\begin{array}{c}p 0.119, \\
n=32)\end{array}\right.\end{array}$ & $\begin{array}{c}\text { Summer } \\
\left(\begin{array}{c}p 0.007, \\
n=32)\end{array}\right.\end{array}$ \\
\hline CS vs. AG + CS & N/A & N/A & $\mathrm{N} / \mathrm{A}$ & $p<0.0001$ & $\mathrm{p}<0.0001$ & p 0.923 & $p<0.0001$ & p 0.0001 & $\mathrm{~N} / \mathrm{A}$ & $\mathrm{N} / \mathrm{A}$ \\
\hline CS vs. AF + CS & $p<0.0001$ & $p<0.0001$ & $p<0.0001$ & $p 0.205$ & $p 0.308$ & $p 0.233$ & $p 0.010$ & $p 0.001$ & $\mathrm{~N} / \mathrm{A}$ & $\mathrm{N} / \mathrm{A}$ \\
\hline CS vs. NP + CS & $p<0.0001$ & $p<0.0001$ & $p<0.0001$ & $p<0.0001$ & $p 0.077$ & $p 0.025$ & $p 0.582$ & $p 0.379$ & $p 0.651$ & p 0.149 \\
\hline
\end{tabular}

$\mathrm{N} / \mathrm{A}=$ data not available. In each row, italicized $p$ values indicate higher $C$. solstitialis cover in CS monocultures, and bolded values are significant at $p<0.05$.

Table 3. Linear contrasts of Centaurea solstitialis cover between mixed plant communities $(\mathrm{AG}=$ annual grasses; $\mathrm{AF}=$ annual forbs; $\mathrm{NP}=$ native perennials; FP = annual forbs and perennials; $\mathrm{EG}=$ Elymus glaucus; $\mathrm{GC}=$ Grindelia camporum; $\mathrm{CS}=\mathrm{C}$. solstitialis) with and without $\mathrm{CS}$.

\begin{tabular}{|c|c|c|c|c|c|c|c|c|c|c|}
\hline \multirow[b]{2}{*}{$\begin{array}{l}\text { Treatment } \\
\text { Contrast }\end{array}$} & \multicolumn{2}{|c|}{2002} & \multicolumn{2}{|c|}{2003} & \multicolumn{2}{|c|}{2004} & \multicolumn{2}{|c|}{2005} & \multicolumn{2}{|c|}{2006} \\
\hline & $\begin{array}{c}\text { Spring } \\
\left(\begin{array}{c}p 0.072, \\
n=24)\end{array}\right.\end{array}$ & $\begin{array}{c}\text { Summer } \\
(p<0.0001, \\
n=30)\end{array}$ & $\begin{array}{c}\text { Spring } \\
(p<0.0001, \\
n=30)\end{array}$ & $\begin{array}{c}\text { Summer } \\
(p<0.0001, \\
n=40)\end{array}$ & $\begin{array}{c}\text { Spring } \\
(p<0.0001, \\
n=40)\end{array}$ & $\begin{array}{c}\text { Summer } \\
(p 0.0002, \\
n=40)\end{array}$ & $\begin{array}{c}\text { Spring } \\
(p<0.0001, \\
n=40)\end{array}$ & $\begin{array}{c}\text { Summer } \\
(p<0.0001, \\
n=40)\end{array}$ & $\begin{array}{c}\text { Spring } \\
p 0.536, \\
n=20)\end{array}$ & $\begin{array}{l}\text { Summer } \\
\begin{array}{c}(p 0.441, \\
n=20)\end{array}\end{array}$ \\
\hline$A G$ vs. $A G+C S$ & $\mathrm{~N} / \mathrm{A}$ & N/A & N/A & $p 0.033$ & $p 0.741$ & $p 0.641$ & $p 0.0003$ & $p 0.082$ & $\mathrm{~N} / \mathrm{A}$ & $\mathrm{N} / \mathrm{A}$ \\
\hline$A F$ vs. $A F+C S$ & $p 0.007$ & $p<0.0001$ & $p<0.0001$ & $p<0.0001$ & $p<0.0001$ & $p 0.0002$ & $p<0.0001$ & $p<0.0001$ & $\mathrm{~N} / \mathrm{A}$ & $\mathrm{N} / \mathrm{A}$ \\
\hline NP vs. NP + CS & $p 0.085$ & $p 0.407$ & $p 1.000$ & $p 0.968$ & $p 0.833$ & $p 0.714$ & $p 0.022$ & $p 0.0001$ & $p 0.753$ & $p 0.658$ \\
\hline FP vs. FP + CS & $p 0.085$ & $p 0.015$ & $p 1.000$ & $p 0.747$ & $p 1.000$ & $p 0.714$ & $p 0.870$ & $p 0.115$ & $p 0.189$ & $p 0.122$ \\
\hline
\end{tabular}

In each row, italicized $p$ values indicate higher C. solstitialis cover in mixed plant communities without CS, and bolded values are significant at $p<0.05$.

Table 4. Linear contrasts of Elymus glaucus cover between mixed plant communities ( $\mathrm{AG}=$ annual grasses; $\mathrm{AF}=$ annual forbs; $\mathrm{NP}=$ native perennials; $\mathrm{FP}=$ annual forbs and perennials; $\mathrm{EG}=E$. glaucus; $\mathrm{GC}=$ Grindelia camporum; $\mathrm{CS}=$ Centaurea solstitialis) with and without $\mathrm{C}$. solstitialis, and between E. glaucus monocultures (EG + CS) and mixed communities with C. solstitialis (NP + CS and FP + CS).

\begin{tabular}{|c|c|c|c|c|c|c|c|c|c|c|}
\hline \multirow{2}{*}{$\begin{array}{l}\text { Treatment } \\
\text { Contrast }\end{array}$} & \multicolumn{2}{|c|}{2002} & \multicolumn{2}{|c|}{2003} & \multicolumn{2}{|c|}{2004} & \multicolumn{2}{|c|}{2005} & \multicolumn{2}{|c|}{2006} \\
\hline & $\begin{array}{c}\text { Spring } \\
(p<0.0001,\end{array}$ & $\begin{array}{c}\text { Summer } \\
(p<0.0001,\end{array}$ & $\begin{array}{c}\text { Spring } \\
(p<0.0001,\end{array}$ & Summer & $\begin{array}{c}\text { Spring } \\
(p<0.0001,\end{array}$ & $\begin{array}{c}\text { Summer } \\
(p<0.0001,\end{array}$ & $\begin{array}{c}\text { Spring } \\
(p<0.0001, \\
n=60)\end{array}$ & $\begin{array}{c}\text { Summer } \\
(p<0.0001,\end{array}$ & $\begin{array}{c}\text { Spring } \\
(p<0.0001,\end{array}$ & $\begin{array}{c}\text { Summer } \\
(p<0.0001,\end{array}$ \\
\hline NP vs. NP + CS & $p 0.017$ & $p 0.149$ & $p 0.006$ & N/A & $p 0.031$ & $p 0.033$ & $p<0.0001$ & $p 0.0002$ & $p 0.072$ & $p 0.113$ \\
\hline FP vs. FP + CS & p 1.000 & $p 0.762$ & $p 0.942$ & N/A & p 0.189 & p 0.052 & $p 0.038$ & $\mathrm{p} 0.532$ & $p 0.295$ & $p<0.0001$ \\
\hline $\mathrm{EG}+\mathrm{CS}$ vs. NP + CS & $p 0.387$ & $p 0.860$ & $p<0.0001$ & $\mathrm{~N} / \mathrm{A}$ & $p 0.0004$ & $p 0.0002$ & $p 0.010$ & $p 0.025$ & $\mathrm{~N} / \mathrm{A}$ & $\mathrm{N} / \mathrm{A}$ \\
\hline $\mathrm{EG}+\mathrm{CS}$ vs. $\mathrm{FP}+\mathrm{CS}$ & $p<0.0001$ & $p<0.0001$ & $p<0.0001$ & $\mathrm{~N} / \mathrm{A}$ & $p 0.001$ & $p 0.007$ & $p 0.634$ & p 0.362 & $\mathrm{~N} / \mathrm{A}$ & $\mathrm{N} / \mathrm{A}$ \\
\hline
\end{tabular}

In each row, italicized $p$ values indicate higher E. glaucus cover in communities without C. solstitialis or in E. glaucus monocultures, and bolded values are significant at $p<0.05$. 
Table 5. Linear contrasts of Grindelia camporum cover between mixed plant communities (AG = annual grasses; $\mathrm{AF}=$ annual forbs; $\mathrm{NP}=$ native perennials; $\mathrm{FP}=$ annual forbs and perennials; $\mathrm{EG}=$ Elymus glaucus; $\mathrm{GC}=\mathrm{G}$. camporum; $\mathrm{CS}=$ Centaurea solstitialis) with and without $C$. solstitialis, and between G. camporum monocultures (GC + CS) and mixed communities with C. solstitialis (NP + CS and FP + CS).

\begin{tabular}{|c|c|c|c|c|c|c|c|}
\hline Treatment Contrast & \multicolumn{2}{|c|}{2002} & \multicolumn{2}{|c|}{2003} & \multicolumn{2}{|c|}{2004} & $\begin{array}{c}2005 \\
\text { Summer } \\
\left(\begin{array}{c}p \\
0.041, \\
n=60)\end{array}\right.\end{array}$ \\
\hline $\mathrm{NP}$ vs. NP + CS & $p 0.072$ & $p 0.881$ & $p 0.944$ & $p 0.005$ & $p 0.670$ & $p 0.374$ & $p 0.895$ \\
\hline $\mathrm{FP}$ vs. $\mathrm{FP}+\mathrm{CS}$ & $p 0.973$ & $p 0.215$ & $p 0.033$ & $p<0.0001$ & $p 0.189$ & $p 0.176$ & $p 0.895$ \\
\hline $\mathrm{GC}+\mathrm{CS}$ vs. NP + CS & $p 0.0007$ & $p<0.0001$ & $p 0.0003$ & $p<0.0001$ & $p 0.132$ & p 0.028 & $p 0.895$ \\
\hline
\end{tabular}

In each row, italicized $p$ values indicate higher G. camporum cover in communities without C. solstitialis or in G. camporum monocultures, and bolded values are significant at $p<0.05$.

\section{Discussion}

\section{Early-Season Communities}

In this study, Centaurea solstitialis readily invaded nonnative annual grass and native annual forb communities. Centaurea solstitialis became dominant in AG and AG + CS plots within 1 year after introduction. Likewise, C. solstitialis rapidly invades California rangelands dominated by non-native annual grasses (Roché \& Roché 1991; Roché et al. 1994; DiTomaso 2000). The invasion trajectory of C. solstitialis in annual grasslands is heavily influenced by the amount of spring precipitation (Enloe et al. 2004; Young 2007). In this study, spring (March to May) precipitation during 2004 was $16 \%$ of the long-term average, whereas spring 2005 was $100 \%$ of the long-term average. As a result, C. solstitialis cover in AG and AG + CS plots was higher in spring (57-61\%) than summer (25-29\%) 2004, likely a result of self-thinning following the dry spring. However, following a normal spring precipitation (2005), C. solstitialis cover increased from spring to summer. By contrast, in the CS monoculture, C. solstitialis cover was apparently too low $(\sim 11 \%)$ to experience self-thinning in 2004 (Kyser \& DiTomaso, personal observation) and actually increased in summer despite the low spring rainfall.

Native annual forbs dominated all early-season AF and the early/late-season FP plots in spring 2002 (50-95\%) but then declined in subsequent years and did not establish outside their plots. Although somewhat better competitors with $C$. solstitialis than the non-native annual grasses, the native annual forbs were unable to prevent invasion of $C$. solstitialis or the establishment of E. glaucus. We observed seed production in all early-season species and therefore do not attribute their decline to seed limitation. Both nonnative annual grasses and native annual forbs are functionally dissimilar to $C$. solstitialis in timing of resource acquisition and were not expected to resist invasion.

Cover of C. solstitialis in CS plots reached a peak in the season following seeding (summer 2002) and declined in all subsequent years. This may have been partly due to intense intraspecific competition (Roché et al. 1997). Furthermore, the accumulation of C. solstitialis standing and ground litter after 2002 reduced light penetration through the canopy, potentially suppressing C. solstitialis growth in the following years. Light at the soil surface in May and July 2002 (the first year of establishment, with high C. solstitialis cover and no thatch) was 13 and $26 \%$ of full sunlight, respectively (Young 2007). From 2003 to 2005, however, light at the soil surface in CS plots ranged between 3 and $6 \%$ during May and July. During these years, C. solstitialis cover decreased to between 21 and $44 \%$. Centaurea solstitialis has been shown to require high light levels (>20\% of full sun) to survive (Roché et al. 1994; DiTomaso et al. 2003).

\section{Late-Season Communities}

Plant species that are functionally similar to C. solstitialis are expected to provide the highest level of competitive resistance to invasion (Zavaleta \& Hulvey 2007). However, G. camporum, selected for this study due to its functional similarities to $C$. solstitialis, proved to be a poor competitor over time not only with $C$. solstitialis but also with other annual and perennial species. Thus, G. camporum appears to be an early-succession species and a good colonizer in newly restored or disturbed plant communities but is not tolerant to mowing or heavy grazing. Grindelia camporum is not sustainable in these systems and is not likely to provide long-term suppression of $C$. solstitialis.

Establishment and subsequent dominance of E. glaucus in native plant communities suppressed invasion by $C$. solstitialis. Although different from C. solstitialis in its morphology, taxonomic classification, life cycle, root architecture, and phenology, E. glaucus is functionally similar to C. solstitialis in its timing of resource acquisition. Persistence of E. glaucus in the Central Valley is due to its extensive root system capable of accessing deep soil moisture and, thus, avoiding competition with shallow-rooted annual species (Dyer \& Rice 1997; Clary et al. 2004). However, establishment of perennial grasses is suppressed by competition from non-native annual species during the critical period of seedling development (Enloe et al. 2005). Not surprisingly, rangelands throughout much of California are dominated by non-native annual grass species, which gen- 
erally resist reestablishment of native perennial grasses, including E. glaucus.

Colonization by E. glaucus, where it was not intentionally seeded, appears to depend on the functional group composition of the invaded plant community. The eventual dominance of E. glaucus in FP and NP plant communities, with and without $C$. solstitialis, demonstrates its competitive potential. Timing of resource utilization has a greater impact on competitive interaction than do morphological or phenological similarities (Jackson \& Roy 1986; Rice 1989; Holmes \& Rice 1996).

\section{Conclusions}

Under our site conditions, seeded communities containing Elymus glaucus resisted invasion of Centaurea solstitialis for at least 5 years after establishment. Within 3 years of seeding, E. glaucus became dominant in all communities where it was planted. Moreover, it spread from seeded sites to establish in other plots, including those planted only to C. solstitialis. Grindelia camporum, a late-season native perennial forb with a similar growth habit to C. solstitialis, established rapidly but was replaced by other species within 3 years.

Functional differences among plant species can influence their interaction and may affect their ability to resist non-native plant invasion. Species from a common functional group may differ in their ability to compete within a community because of other environmental constraints (Zavaleta \& Hulvey 2007). Under the conditions present in this study, E. glaucus, which is functionally similar in resource utilization to $C$. solstitialis, was able to not only resist invasion but also proliferate.

With C. solstitialis replacing populations of non-native annual grasses throughout much of California's grasslands, the management and ecological benefits of native perennial grasses, especially E. glaucus, will be of increasing importance (Rossiter et al. 2003; De Luis et al. 2004; Jankauskas et al. 2004). In addition to erosion control and reduced wildfire hazard, establishment of native perennial grass communities has the potential benefit of resisting invasion by non-native species.

\section{Implications for Practice}

Communities with high species diversity are not necessarily the most resistant to invasion.

High species diversity in seed mixes will not always result in a stable high-diversity community.

Grassland restoration programs should consider using species that are not only capable of establishing and proliferating but also overlap in their timing of resource acquisition with potential high-risk invaders.

\section{Literature Cited}

Benefield, C. B., J. M. DiTomaso, G. B. Kyser, A. Tschohl. 2001. Reproductive biology of yellow starthistle: maximizing late season control. Weed Science 49:83-90.

Brown, C. S., K. J. Rice, V. P. Claassen. 1998. Competitive growth characteristics of native and exotic grasses. Federal Highway Association (FHWA)/CA/ESC-98/07. California Department of Transportation, Sacramento, California.

Bugg, R. L., C. S. Brown, J. H. Anderson. 1997. Restoring native perennial grasses to rural roadsides in the Sacramento Valley of California: establishment and evaluation. Restoration Ecology 5:214-228.

Burcham, L. T. 1956. Historical backgrounds of range land use in California. Journal of Range Management 9:81-86.

Clary, J., R. Save, C. Biel, F. de Herralde. 2004. Water relations in competitive interactions of Mediterranean grasses and shrubs. Annals of Applied Biology 144:149-155.

Daniel, W. W. 1999. Analysis of variance. Pages 334-341 in W. W. Daniel, editor. Biostatistics: a foundation for analysis in the health sciences. John Wiley \& Sons, Inc, Hoboken, New Jersey.

De Luis, M., J. Raventos, J. Cortina, J. C. Gonzalez-Hidalgo, J. R. Sanchez. 2004. Fire and torrential rainfall: effects on the perennial grass Brachypodium retusum. Plant Ecology 173:225-232.

Diaz S., S. Lavorel, F. S. Chapin, P. A. Tecco, D. E. Gurvich, K. Grigulis. 2007. Functional diversity-at the crossroads between ecosystem functioning and environmental filters. Pages 81-91 in J. G. Canadell, D. E. Pataki, L. F. Pitelka, editors. Terrestrial ecosystems in a changing world. Springer Berlin Heidelberg, New York.

DiTomaso, J. M. 2000. Invasive weeds in rangelands: species, impacts, and management. Weed Science 48:255-265.

DiTomaso, J. M., E. A. Healy. 2007. Weeds of California and other western states. Publication \#3488. University of California, Agriculture and Natural Resources, Oakland.

DiTomaso, J. M., G. B. Kyser, M. S. Hastings. 1999. Prescribed burning for control of yellow starthistle (Centaurea solstitialis) and enhanced native plant diversity. Weed Science 47:233-242.

DiTomaso, J. M., G. B. Kyser, S. B. Orloff, S. F. Enloe. 2000. Integrated strategies offer site-specific control of yellow starthistle. California Agriculture 54:30-36.

DiTomaso, J. M., G. B. Kyser, C. B. Pirosko. 2003. Effect of light and density on yellow starthistle (Centaurea solstitialis) root growth and soil moisture use. Weed Science 51:334-341.

Dyer, A. R., K. J. Rice. 1997. Intraspecific and diffuse competition: the response of Nassella pulchra in a California grassland. Ecological Applications 7:484-492.

Elton, C. S. 1958. The ecology of invasions by animals and plants. Methuen, London, United Kingdom.

Enloe, S. F., J. M. DiTomaso, S. Orloff, D. Drake. 2004. Soil water dynamics differ among rangeland plant communities dominated by yellow starthistle (Centaurea solstitialis), annual grasses, or perennial grasses. Weed Science 52:929-935.

Enloe, S. F., J. M. DiTomaso, S. Orloff, D. Drake. 2005. Perennial grass establishment integrated with clopyralid treatment for yellow starthistle management on annual range. Weed Technology 19:94-101.

Gerlach, J. D. 1997a. How the west was lost: reconstructing the invasion dynamics of yellow starthistle and other plant invaders of western rangelands and natural areas. Proceedings of the California Exotic Pest Plant Council Symposium 3:67-72. 
Gerlach, J. D. 1997b. The introduction, dynamics of geographic range expansion, and ecosystem effects of yellow starthistle (Centaurea solstitialis). Proceedings of the California Weed Science Society 49:136-141.

Gerlach, J. D. 2004. The impacts of serial land-use changes and biological invasions on soil water resources in California, USA. Journal of Arid Environments 57:365-379.

Gerlach, J. D., K. J. Rice. 2003. Testing life history correlates of invasiveness using congeneric plant species. Ecological Applications 13:167-179.

Heady, H. A. 1988. Valley grassland. Pages 491-512 in M. G. Barbour J. Major, editors. Terrestrial vegetation of California. Wiley Interscience, New York.

Hickman, J. C, editor. 1993. The Jepson manual: higher plants of California. University of California Press, Berkeley.

Holmes, T. H., K. J. Rice. 1996. Patterns of growth and soil-water utilization in some exotic annuals and native perennial bunchgrasses of California. Annals of Botany 78:233-243.

Jackson, L. E., J. Roy. 1986. Growth patterns of Mediterranean annual and perennial grasses under simulated rainfall regimes of southern France and California. Acta Oecologica 7:191-212.

Jankauskas, B., G. Jankauskiene, M. A. Fullen. 2004. Erosion-preventive crop rotations and water erosion rates on undulating slopes in Lithuania. Canadian Journal of Soil Science 84:177-186.

Knapp, E. E., K. J. Rice. 1996. Genetic structure and gene flow in Elymus glaucus (blue wildrye): implications for native grassland restoration. Restoration Ecology 4:1-10.

Lavorel, S., S. Diaz, J. C. Cornelissen, E. Garnier, S. P. Harrison, S. McIntyre, J. G. Pausas, N. Perez-Harguindeguy, C. Roumet, C. Urcelay. 2007. Plant functional types: are we getting any closer to the Holy Grail? Pages 149-164 in J. G. Canadell, D. E. Pataki, L. F. Pitelka, editors. Terrestrial ecosystems in a changing world. Springer Berlin Heidelberg, New York.

McNaughton, S. J. 1968. Structure and function in California grasslands. Ecology 49:962-972.

Pitcairn, M. J., S. Schoenig, R. Yacoub, J. M. Gendron. 2006. Yellow starthistle continues its spread in California. California Agriculture 60:83-90.

Rice, K. J. 1989. Competitive interactions in California annual grasslands. Pages 59-71 in L. F. Huenneke H. A. Mooney, editors. Grassland structure and function: California annual grassland. Kluwer Academic, Dordrecht, Netherlands.

Rice K. J., J. D. Gerlach, A. R. Dryer. 1997. Closed canopies and open niches: patterns and mechanisms of sequential invasion in California grasslands. Bulletin of the Ecological Society of America 78:30.
Robinson, G. R., J. F. Quinn, M. L. Stanton. 1995. Invasibility of experimental habitat islands in a California winter annual grassland. Ecology 76:786-794.

Roché, B. F. Jr., C. T. Roché. 1991. Identification, introduction, distribution, ecology, and economics of Centaurea species. Pages 274-291 in L. F. James, J. O. Evans, M. H. Ralphs, R. D. Child, editors. Noxious range weeds. Westview Press, San Francisco, California.

Roché, B. F. Jr., C. T. Roché, R. C. Chapman. 1994. Impacts of grassland habitat on yellow starthistle (Centaurea solstitialis L.) invasion. Northwest Science 68:86-96.

Roché, C. T., D. C. Thill, B. Shafii. 1997. Reproductive phenology in yellow starthistle (Centaurea solstitialis). Weed Science 45:763-770.

Rossiter, N. A., S. A. Setterfield, M. M. Douglas, L. B. Hutley. 2003. Testing the grass-fire cycle: alien grass invasion in the tropical savannas of northern Australia. Diversity and Distributions 9:169-176.

SAS. 2002. SAS ${ }^{\circledR}$ version 9.1 .3 for Windows. SAS Institute Inc, Cary, North Carolina.

Scheiner, S. M. 2001. MANOVA: multiple response variables and multispecies interactions. Pages $99-115$ in S. M. Scheiner J. Gurevitch, editors. Design and analysis of ecological experiments. Oxford University Press, Inc, New York.

Sheley, R. L., L. L. Larson, D. E. Johnson. 1993. Germination and root dynamics of range weeds and forage species. Weed Technology 7:234-237.

Symstad, A. J. 2000. A test of the effects of functional group richness and composition on grassland invasibility. Ecology 81:99-109.

Tilman, D. 1997. Community invasibility, recruitment limitation and grassland biodiversity. Ecology 78:81-92.

Tilman, D., D. Wedin, J. Knops. 1996. Productivity and sustainability influenced by biodiversity in grassland ecosystems. Nature 379:718-720.

Vitousek, P. M., D. U. Hooper. 1997. The effects of plant composition and diversity on ecosystem processes. Science 277:1302-1305.

Young, S. L. 2007. The effects of species diversity and soil water dynamics on the invasion by yellow starthistle (Centaurea solstitialis) into established California Central Valley plant communities. Ph.D. dissertation. University of California, Davis.

Zavaleta, E. S., K. B. Hulvey. 2007. Realistic variation in species composition affects grassland production, resource use and invasion resistance. Plant Ecology 188:39-51. 